\title{
Balloniscus glaber (Crustacea, Isopoda, Balloniscidae), a habitat specialist species in a disturbed area of Brazil
}

\author{
Diego Costa Kenne \& Paula Beatriz Araujo
} Programa de Pós-graduação em Biologia Animal, Departamento de Zoologia, Instituto de Biociências, Universidade Federal do Rio Grande do Sul,
Av. Bento Gonçalves, 9500, Bairro Agronomia, 91501-970 Porto Alegre, RS, Brazil. (diegokenne@gmail.com; pabearaujo@gmail.com)

\begin{abstract}
Balloniscus glaber Araujo \& Zardo, 1995 (Balloniscidae), a Neotropical Oniscidea, has been recorded historically in environments with low or no human interference. In one of these areas, it was determined as a $K$-strategist. Recently, however, this species was documented in a disturbed forest within urban limits. The present work revealed that the population in the urban area has high density, high number of ovigerous females and mancae in the population, a long reproductive period, and early sexual maturity. These results suggest that modified environments may provide favorable conditions and that the species is not negatively affected by human influence.
\end{abstract}

KEYWORDS. Human interference, anthropogenic influence, population ecology, $K$-strategist, terrestrial isopods.

RESUMO. Balloniscus glaber (Crustacea, Isopoda, Balloniscidae), uma espécie especialista de hábitat em uma área perturbada do Brasil. Balloniscus glaber Araujo \& Zardo, 1995 (Balloniscidae), um oniscídeo Neotropical, tem sido registrado historicamente em ambientes com baixa ou sem interferência humana. Em uma dessas áreas, a espécie foi classificada como $K$-estrategista. No entanto, recentemente foi registrada em uma floresta perturbada dentro dos limites urbanos. O presente trabalho revela que a população na área urbana tem densidade alta, elevado número de fêmeas ovígeras e mancas, período reprodutivo longo e maturidade sexual precoce. Estes resultados sugerem que um ambiente modificado pode proporcionar condições favoráveis e que a espécie não é afetada negativamente pela influência humana.

PALAVRAS-CHAVE. Interferência humana, influência antropogência, ecologia populacional, $K$-estrategista, isópodos terrestres.

In population and community ecology studies, habitat fragmentation has often been considered the most influential factor affecting species distribution and abundance in natural communities (KITAHARA et al., 2000). In addition to fragmentation, trampling (which results in, e.g., paths, trails, and roads) is a common activity in urban woodlands, contributing to the abrasion of habitats near residential areas (LEHVÄVIRTA et al., 2006). Trampling induces reductions in the litter cover of soils by decreasing undergrowth vegetation and affecting resprouting ability, as demonstrated by the appearance of eroded areas (LEHVÄVIRTA et al., 2006). In recent history, some habitats have been lost or diminished through urbanization, while new habitats have been created as urban green spaces, which are important for biodiversity by acting as wildlife refugia and genetic reservoirs (JONES \& LEATHER, 2012 and references). Species respond differently to urbanization either in abundance, diversity, or both, and both negative (decline) and positive (higher, refugia) correlations may occur (JoNES \& LEATHER, 2012). In this scenario we would expect urbanization to favor generalist species (KITAHARA \& FUJII, 1994) and according to the habitat specialist hypothesis (MAGURA et al., 2004), alteration of the original conditions in a disturbed area could prevent the colonization by specialist species.

According to Hassall et al. (2005), the environmental factors related to the life history, population strategies, attributes, and reproductive behavior that influence terrestrial isopod growth and survival, still remain to be clarified. Ecological and demographic data are of paramount importance for population studies because they provide information on a population's distribution, size, niche, age, and sex ratio. Such information can help us to understand how individuals adapt to the environment where they live and possibly to new habitats such as urban green spaces. Habitat instability, shelter availability, and food quality are of primarily importance for terrestrial isopod abundance and spatial distribution (HoRNUNG, 1991; HeInZelmann et al., 1995; Jabin et al., 2004; HoRNUNG et al., 2007). Small fluctuations in the variables that regulate microhabitats in which terrestrial isopods occur are remarkably important because they can lead to changes in species abundance and diversity (VILISICS et al., 2011; Ferenti \& Covaciu-Marcov, 2012). Although some previous studies have addressed the community structure or diversity of arthropods (MAGURA et al., 2004; Jones \& LEATHER, 2012), and terrestrial isopods in particular (MAGURA et al., 2008), little is known about the response of particular species to urbanization.

Currently, few reports have addressed anthropogenic effects and terrestrial isopods' response behaviors in the Neotropics (AlmERÃo et al., 2006; MAGRINI et al., 2011). The results of AlMERÃo et al. (2006) showed that the highest abundance of Balloniscus glaber Araujo \& Zardo, 1995 in Parque Estadual de Itapuã (PEI), referred as a nonurban area, in southern Brazil, occurred along a trail closed to visitors. Later, QUADROs et al. (2009), studying the same species from the same area, concluded that $B$. glaber is a habitat specialist species that shows $K$-selected traits. Recently, a population of B. glaber was found in a 
disturbed area within the limits of the city of Porto Alegre, RS, Brazil, close to PEI. At first glance, this population appeared to present a different pattern of abundance than that found in previous studies. This observation led us to ask: what life history modifications have made it possible for a habitat specialist species to survive and maintain a viable population under human disturbance in a fragmented habitat or urban area?

\section{MATERIAL AND METHODS}

Studied species. Based on the scarce information available on the distribution and biology of this species, BOND-BUCKUP et al. (2003) categorized it as data deficient (DD) in the Rio Grande do Sul Endangered Species List. However, the species does not appear in the recent evaluation of that list (RIo GRANDE Do Sul, 2014), since for the new evaluation, several ecological information was already available. Only ten years after the description of $B$. glaber, the species was recorded in three distinct altitudinal gradients in the state of Rio Grande do Sul (Lopes et al., 2005). MeINHARDT et al. (2007) described its species' growth curve and demonstrated that females reach a larger size, live longer, and have a slower growth rate compared to males. QUADRos et al. (2009) investigated two sympatric populations of Atlantoscia floridana (van Name, 1940) and B. glaber at PEI and found that females of the latter species became reproductive at approximately 7.5 months old and incubated 5-20 eggs for approximately 40 days. This study also demonstrated that B. glaber has a restricted spatial distribution and is mainly associated with Atlantic Forest fragments, a biome threatened by deforestation and monoculture replacement (MORELLATO $\&$ HADDAD, 2000). Also, the same work found that $B$. glaber exhibited $K$-strategist features. This is evidenced by its longer lifetime, later reproductive age, some degree of parental reproductive investment, slower development, and a lower growth rate when compared with A. floridana, a generalist species that exhibited $r$-strategist species patterns. The apparent local requirement for non-impacted habitat combined with the $K$-strategist characteristics of $B$. glaber (SUTTON et al., 1984) may contribute to its threat of extinction (QUADROS et al., 2009).

Study area and samples. The isopods were sampled in a forest fragment of approximately $1,300 \mathrm{~m}^{2}$, in Porto Alegre, RS, Brazil: $30^{\circ} 20^{\prime} \mathrm{S}, 51^{\circ} 16^{\prime} \mathrm{W}$ at the Fundação de Proteção Especial do Rio Grande do Sul (Fig. 1). The vegetation is similar to that of PEI (historically and presently), characterized by a secondary forest in an urban area composed of 30 years old shrubs and trees. In this fragment an area of approximately $200 \mathrm{~m}^{2}$ presents a large accumulation of litter, in addition to the deposition of disposables from neighborhood residences (e.g., wood, toys, packaging, clothing, kitchenware, furniture, and other human-made objects). In this particular fragment, a $10 \mathrm{~m}$ wide and $18 \mathrm{~m}$ long area was demarcated and divided into 180 quadrats $(1 \mathrm{~m} \times 1 \mathrm{~m}$ each $)$. Monthly,
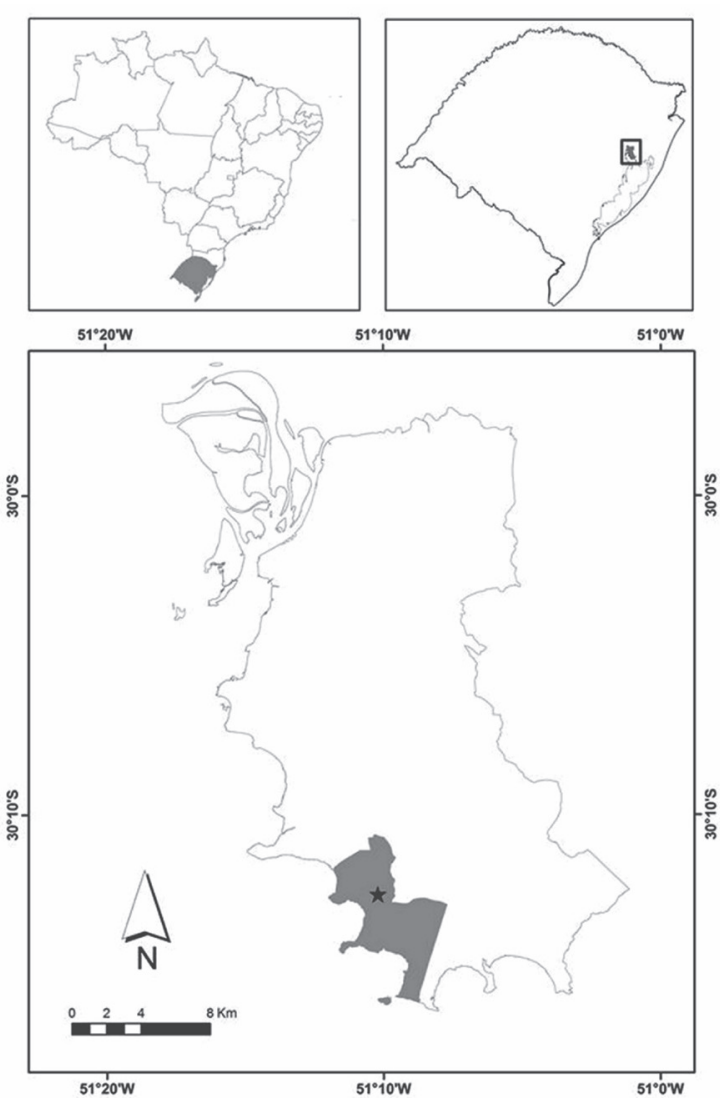

Fig. 1. Porto Alegre, RS, Brazil. The star shows where Balloniscus glaber Araujo \& Zardo, 1995, soil and litter were sampled.

from July 2011 to June 2012, individuals were captured from 10 randomly selected quadrants. A $30 \mathrm{~cm}$ diameter corer was used to collect litter and approximately $3 \mathrm{~cm}$ of superficial soil. Samples were placed in plastic bags and sorted in the laboratory. For each sample quadrat, the litter and soil temperature $\left({ }^{\circ} \mathrm{C}\right)$ and relative moisture $(\%)$ were measured with a thermo-hygrometer. Air temperature $\left({ }^{\circ} \mathrm{C}\right)$ and relative humidity (\%) measurements were obtained from the Instituto Nacional de Meteorologia (INMET, 2012). The regional climate is temperate and considered $\mathrm{CFa}$ according to Köppen-Geiger (PEEL et al., 2007), with hot summers and no dry season.

Laboratory analyses. The animals were sorted from the litter manually and fixed in $70 \%$ ethanol. Ovigerous females were fixed individually to preserve the marsupial content (number of eggs, embryos, and mancae) because they release their offspring when placed into ethanol. The remaining soil samples were processed in the Berlese funnel extractor (ARAUJO \& BOND-BUCKUP, 2005). After this process, the isopods were grouped by life stages and sex, and the cephalothorax width (CW) was measured in millimeters (ARAUjo et al., 2004). Animals that possessed a $\mathrm{CW}$ between $0.73 \mathrm{~mm}$ and $0.83 \mathrm{~mm}$ (the smallest male $\mathrm{CW}$ ) were grouped into the category "undifferentiated". This category was created based on our inability to distinguish the sex of smaller non-manca individuals.

Statistical analyses. The density data were $\log _{10}$ 
$(n+1)$ transformed as in Araujo \& Bond-Buckup (2005), and the CW values were arranged by month and interval class in histograms (I-XXI) (MeINHARDT et al., 2007). Following Araujo \& Bond-Buckup (2005), the reproductive period was defined, as the monthly operational sex ratio (OSR), which is based on the rate of males and females that are apt to reproduce at a given time (EMLEN \& ORING, 1997), and the ovigerous females' categorization (females with eggs, EG; females with embryos, EM; females with manca, MA; and post-ovigerous females, $\mathrm{PO})$. The adult's minimum CW ( $\mathrm{mm}$ ) size determination followed QuADros et al. (2009). The potential reproductive females (PRF), the actual reproductive females (ARF), and the index of reproduction mobilization (IRM) were calculated following Quadros \& Araujo (2007), as well as the index of maximum reproduction mobilization $\left(\mathrm{IRM}_{\text {max }}\right)$ assuming that all females were reproductive (i.e., $\mathrm{PRF}=1$ and $\mathrm{ARF}=1)$. The intra-marsupial mortality rate was estimated (ARAUjo \& Bond-BUCKUP, 2005), as the relationship between the number of eggs (fecundity) and the females' $\mathrm{CW}$, described by the linear regression equation $\mathrm{F}=\mathrm{a}+\mathrm{b}(\mathrm{CW})$, where $\mathrm{F}$ is fecundity. The formula given by SutTON (1968) was used to calculate egg production: egg production $=($ total number of eggs in a month $\times$ interval between samples)/average development time. The mean intra-marsupial development time used in the equation above was 40 days, as proposed by QuADRos et $a l$. (2009). Multiple regression tests $(\mathrm{p}<0.05)$ were used for correlation analyses between soil temperature $\left({ }^{\circ} \mathrm{C}\right)$ and relative moisture $(\%)$; litter temperature $\left({ }^{\circ} \mathrm{C}\right)$ and relative moisture $(\%)$; air temperature $\left({ }^{\circ} \mathrm{C}\right)$ and relative humidity (\%); and the individual density, after QuAdros \& ARAUJO (2007). Additionally, coefficients of variation (CV) were calculated to express the variation among abiotic variables during the 12 months of sampling.

\section{RESULTS}

Abiotic data. The average soil temperature was $21.2^{\circ} \mathrm{C}$, fluctuating between $13.2^{\circ} \mathrm{C}$ and $28.2^{\circ} \mathrm{C}$ (July 2011 and February 2012, respectively), with a CV of $19.2 \%$. The average litter temperature was $21.5^{\circ} \mathrm{C}$, ranging from $13.3^{\circ} \mathrm{C}$ to $28.7^{\circ} \mathrm{C}$ (July 2011 and February 2012, respectively), with a CV of $19.8 \%$. With respect to relative moisture, both soil and litter had averages of $54 \%$ (soil CV $=15.2 \%$, litter $\mathrm{CV}=15.5 \%$ ), with minimums of $42 \%$ (March 2012) and maximums of $70 \%$ for the soil and $71 \%$ for the litter (August 2011). The minimum observed air temperature ranged from $6^{\circ} \mathrm{C}$ to $21^{\circ} \mathrm{C}$, and the maximum ranged from $15^{\circ} \mathrm{C}$ to $31^{\circ} \mathrm{C}$. The air's relative humidity ranged from $60 \%$ (November 2011) to 90\% (August 2011) (Fig. 2). No relationship was observed between abiotic variables and the total reproductive female density (multiple $\mathrm{R}^{2}=0.64, \mathrm{~F}$ $=4.29, \mathrm{p}=0.07)$ or between abiotic variables and the total animal density (multiple $\mathrm{R}^{2}=0.16, \mathrm{~F}=1.35, \mathrm{p}=0.38$ ).

Population structure. In total, 4,661 individuals were collected: 1,550 males, 2,445 females (2,273 non-
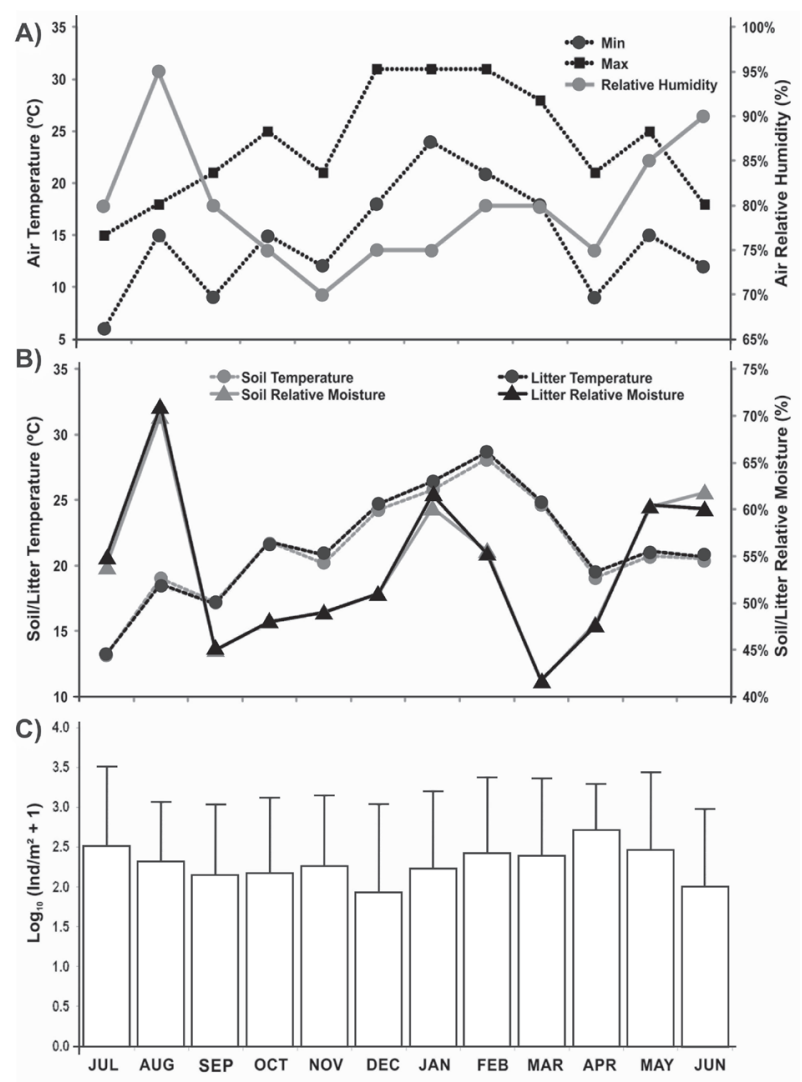

Fig. 2. Monthly Microclimate and Balloniscus glaber Araujo \& Zardo, 1995 density in the disturbed area, Porto Alegre, RS, Brazil, during the 12 months of sampling (Jul/2011 to Jun/2012): A, Air Temperature $\left({ }^{\circ} \mathrm{C}\right.$ ) and Air Relative Humidity (\%); B, Soil/Litter Temperature $\left({ }^{\circ} \mathrm{C}\right)$ and Soil/Litter Relative Moisture (\%); C, Log10 (ind $\left./ \mathrm{m}^{2}+1\right)$ density. For temperature, moisture and humidity, all values are monthly averages. Vertical bars indicate the standard deviation.

ovigerous, 139 ovigerous, and 33 post-ovigerous), 218 undifferentiated and 448 mancae (newborns). The density ranged between $344 \mathrm{ind} / \mathrm{m}^{2}$ (December 2011) and $879 \mathrm{ind} /$ $\mathrm{m}^{2}$ (April 2012) $(\mathrm{CV}=34.4 \%)$, with an average of $556 \mathrm{ind} /$ $\mathrm{m}^{2} \pm 190$ (standard deviation). No significant differences were observed throughout the year (ANOVA: $\mathrm{F}=1.143$, $\mathrm{p}=0.336$ ) or between seasons (ANOVA: $\mathrm{F}=0.497, \mathrm{p}=$ 0.689 ); however, density was lower in the spring and higher in the fall (391 ind $/ \mathrm{m}^{2}$ and $681 \mathrm{ind} / \mathrm{m}^{2}$, respectively). Both males and females displayed a unimodal $\mathrm{CW}$ distribution, with most of the males in class VIII (CW between 1.25 $\mathrm{mm}$ and $1.35 \mathrm{~mm}$ ), non-ovigerous females in class $\mathrm{V}(\mathrm{CW}$ between $0.95 \mathrm{~mm}$ and $1.05 \mathrm{~mm}$ ), and ovigerous females in class X (CW between $1.45 \mathrm{~mm}$ and $1.55 \mathrm{~mm}$ ) (Fig. 3). We observed a prevalence of juvenile animals (mostly females), with over $50 \%$ of the population belonging to the smaller size classes (I-VII, $0.55-1.25 \mathrm{~mm} \mathrm{CW}$ ) during the first month of sampling (winter) and between January and May 2012 (summer and autumn) (Fig. 4). The average male and female sizes $(\mathrm{CW})$ were $1.43 \mathrm{~mm}$ \pm 0.3 (standard deviation) and $1.32 \mathrm{~mm} \pm 0.37$ (standard deviation), respectively, with significant difference between the sexes (ANOVA: $F=98.919, p<0.0001$ ) (Fig. 5). A 
larger size range was observed between the females, and the largest non-ovigerous $\mathrm{CW}$ reached $2.45 \mathrm{~mm}$. The largest male $\mathrm{CW}$ was $2.38 \mathrm{~mm}$.

Sexual ratio and operational sex ratio. The OSR was not significantly different between months, except in August 2011 (female predominance, $\chi^{2}=5.57, p=0.0183$ ) before ovigerous females were present and in January 2012 (male predominance, $\chi^{2}=8.67, p=0.003$ ) (Fig. 6). Female frequencies exceeded male frequencies (considering all males and non-reproductive males and females) for the entire year of sampling, resulting in an average sex ratio of $0.68: 1(ふ:$ ) $)$.

Ovigerous females and post-ovigerous females. The post-ovigerous females and ovigerous females represented $7 \%$ of the total females collected between October 2011 and May 2012, indicating that the breeding season is restricted to this period (Fig. 7). The density ranged from $4.3 \mathrm{ind} / \mathrm{m}^{2}$ in May 2012 (autumn) to $52.9 \mathrm{ind} /$ $\mathrm{m}^{2}$ in January 2012 (summer) and coincided with the period when the OSR favored the males. The smallest ovigerous female sampled had a CW of $1.49 \mathrm{~mm}$, suggesting a minimum size required to reach sexual maturity in this population. The largest ovigerous female was also the largest individual sampled in the population ( $\mathrm{CW}$ of 2.63 $\mathrm{mm}$ ), and it was the only specimen occupying the class XXI size distribution. When reproduction began in October, half of the adult females were potentially reproductive, and this rate increased to $56 \%$ in December. However, only in March 2012 65\% of adult females were actually reproductive. Even with ARF being absent during JulySeptember 2011 and June 2012, PRF were present all year in the population $(24 \%$ in winter and $20 \%$ in the last month of sampling). The highest IRM was observed in January 2012 (30.3\%), followed by November 2011 (18.3\%) and December 2011 (16.0\%) (Tab. I).

Fecundity and intra-marsupial mortality. Ovigerous females were assessed for their intra-marsupial content, resulting in 52.5\% EG, 27.3\% EM, and 20.2\% MA. The presence of unviable eggs (a total of 27 eggs with 379 embryos) was observed in EM, indicating a 6.7\% overall intra-marsupial mortality rate. The highest rate was

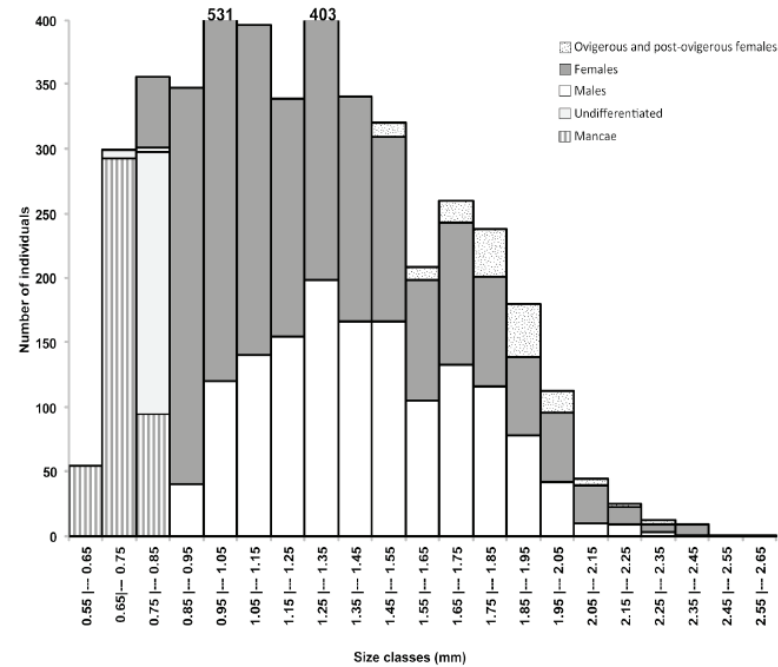

Fig. 3. Histogram of Balloniscus glaber Araujo \& Zardo, 1995 individual distribution in size classes determined by the fourth part of the standard deviation, sampled in the impacted area, Porto Alegre, RS, Brazil, from Jun/2012 Jul/2011. Numbers above the bars show frequency above 400 individuals.

observed in January 2012 (14.1\%), followed by March 2012 (10.7\%) and November 2011 (4\%). The fecundity equation was described as $\mathrm{F}=-20.15+16.63(\mathrm{CW})\left(\mathrm{R}^{2}=\right.$ $0.57, \mathrm{~F}=167.4, \mathrm{p}<0.0001)$. The intra-marsupial content varied from three to 28 , with an average fecundity of 11 eggs \pm 4 (standard deviation) $(\mathrm{EG}=11.1, \mathrm{EM}=10.7, \mathrm{MA}$ $=10.3$ ), and $\mathrm{CV}=36.3 \%$.

Egg production. More eggs were produced in the summer months (January-March 2012), with a total of $342\left(163 \mathrm{eggs} / \mathrm{m}^{2}\right)$. In the spring, the egg production was 300 (143 eggs $/ \mathrm{m}^{2}$ ) (Tab. II). April and May 2012 (final breeding season months) were not considered due to the low frequency of ovigerous females and eggs in the population.

Recruitment. The newborns (free mancae individuals) occurred from October 2011 to June 2012, the month after the last ovigerous female was sampled. The observed manca densities were between 8.6 ind $/ \mathrm{m}^{2}$ (October 2011) and $192.9 \mathrm{ind} / \mathrm{m}^{2}$ (February 2012), with $58 \%$ of them sampled in the summer. The juvenile recruiting

Tab. I. Potentially reproductive females (PRF: adult females/total females), actual reproductive females (ARF: reproductive females/adult females) and the population index of reproduction mobility (IRM: \% $\mathrm{IRM}_{\max }$ ) of the Balloniscus glaber Araujo \& Zardo, 1995 females from each monthly sampling in the impacted area, Porto Alegre, Brazil.

\begin{tabular}{lccc}
\hline Month & $\begin{array}{c}\text { Potentially Reproductive Females } \\
\text { (PRF) }\end{array}$ & $\begin{array}{c}\text { Actual Reproductive Females (ARF) } \\
\text { Index of Reproduction Mobility (IRM) }\end{array}$ \\
\hline Jul/2011 & 0.16 & 0.00 & $0.0 \%$ \\
Aug/2011 & 0.25 & 0.00 & $0.0 \%$ \\
Sep/2011 & 0.39 & 0.00 & $0.0 \%$ \\
Oct/2011 & 0.50 & 0.16 & $8.2 \%$ \\
Nov/2011 & 0.54 & 0.34 & $18.3 \%$ \\
Dec/2011 & 0.56 & 0.28 & $3.0 \%$ \\
Jan/2012 & 0.52 & 0.59 & $30.3 \%$ \\
Feb/2012 & 0.25 & 0.51 & $12.9 \%$ \\
Mar/2012 & 0.23 & 0.65 & $14.8 \%$ \\
Apr/2012 & 0.17 & 0.11 & $1.9 \%$ \\
May/2012 & 0.24 & 0.04 & $1.0 \%$ \\
Jun/2012 & 0.17 & 0.00 & $0.0 \%$ \\
\hline
\end{tabular}



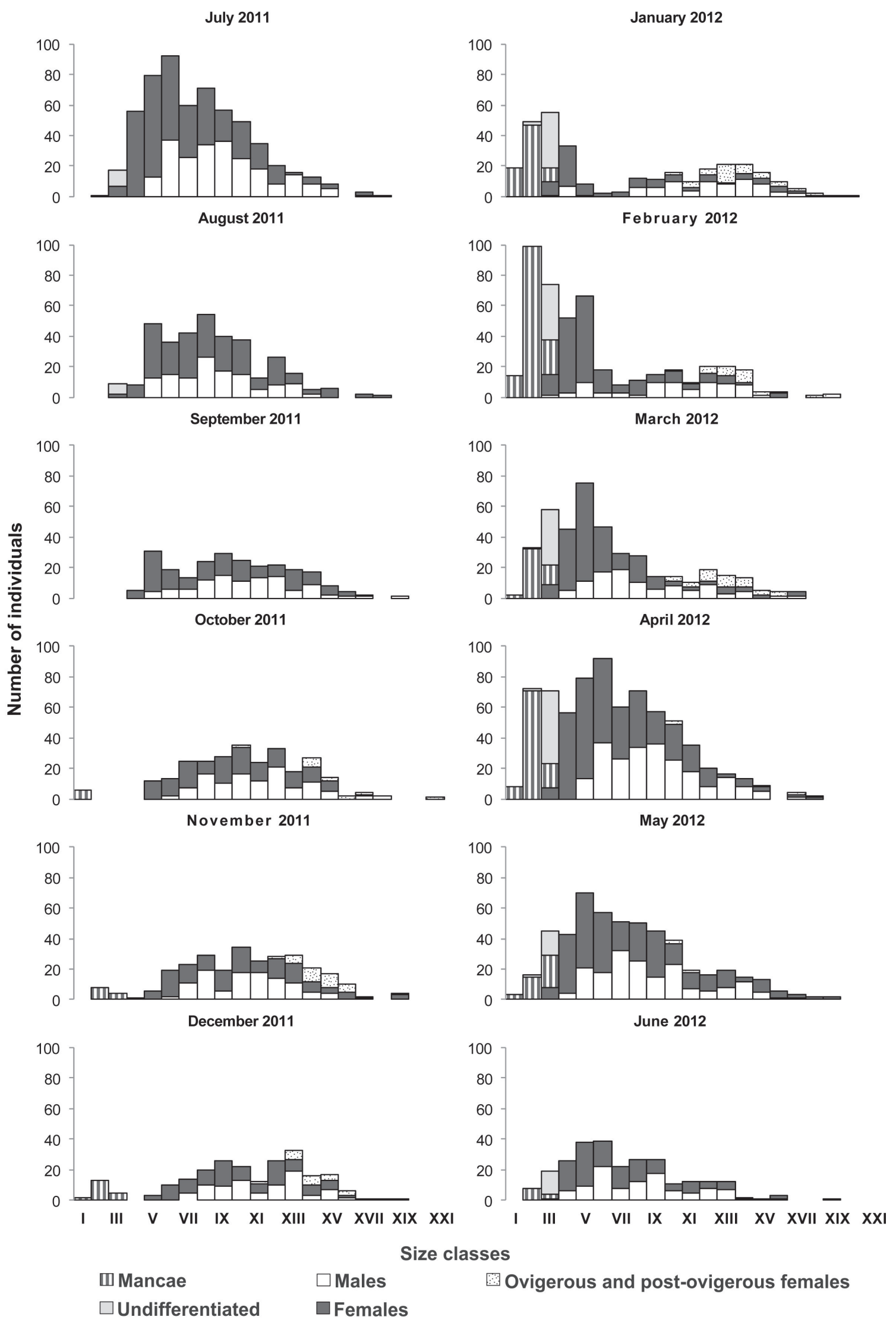

Fig. 4. Number of males, non-ovigerous females, ovigerous females + post-ovigerous females, undifferentiated and mancae of Balloniscus glaber Araujo \& Zardo, 1995, distributed in size classes of the impacted area in Porto Alegre, RS, Brazil, during the 12 months of sampling (Jul/2011 to Jun/2012). 


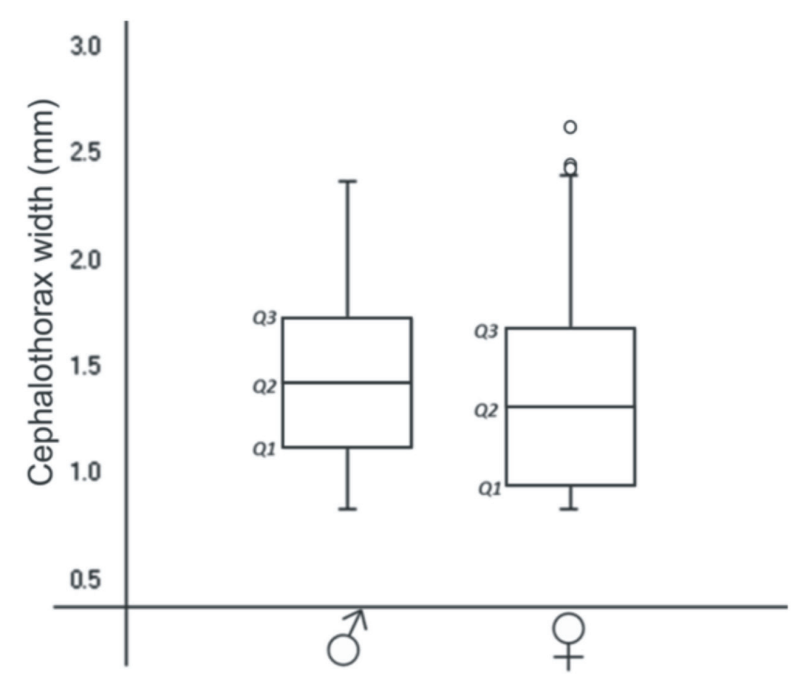

Fig. 5. Box-Plots of Balloniscus glaber Araujo \& Zardo, 1995 total males and females size distribution in the impacted area, Porto Alegre, RS, Brazil. Quartiles Q1 and Q3 represent one standard deviation and Q2 represents the average size. The lower shaft limits show the smallest sizes for both sexes $\left(0.84 \mathrm{~mm}\right.$ of $\mathrm{CW}$ ) and upper shaft (for $\left.{ }^{3}\right)$ and the most extreme outlier (for ? ) show the largest animal size ( $2.38 \mathrm{~mm}$ and $2.63 \mathrm{~mm}$ of $\mathrm{CW}$, respectively).

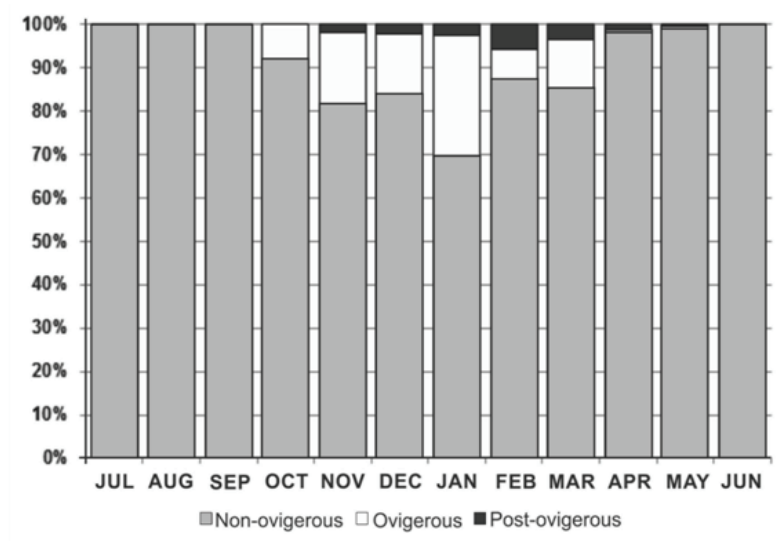

Fig. 6. Total Balloniscus glaber Araujo \& Zardo, 1995 females' relative frequency in the impacted area, Porto Alegre, RS, Brazil, from July 2011 to June 2012.

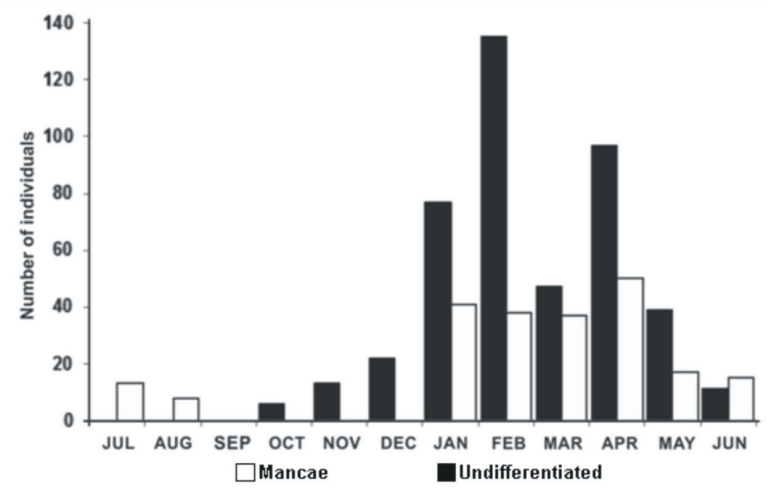

Fig. 7. Number of Balloniscus glaber Araujo \& Zardo, 1995 mancae and undifferentiated individuals sampled from July 2011 to June 2012 in the impacted area, Porto Alegre, RS, Brazil.
Tab. II. Egg production of Balloniscus glaber Araujo \& Zardo, 1995, considering the 2011 spring months (Oct-Nov-Dec) and 2012 summer months (Jan-Feb-Mar) of the impacted area, Porto Alegre, Brazil (OF, ovigerous females).

\begin{tabular}{lcccc}
\hline Date sampled & $\begin{array}{c}\text { Number of } \\
\text { OF }\end{array}$ & $\begin{array}{c}\text { Number of } \\
\text { Eggs }\end{array}$ & $\begin{array}{c}\text { Time interval } \\
\text { between } \\
\text { samples }\end{array}$ & $\begin{array}{c}\text { Egg } \\
\text { Production }\end{array}$ \\
\hline Oct 19, 2011 & 11 & 147 & 37 & 136 \\
Nov 16, 2011 & 13 & 140 & 28 & 98 \\
Dec 12, 2011 & 9 & 102 & 26 & 66 \\
Jan 20, 2012 & 17 & 155 & 39 & 151 \\
Feb 28, 2012 & 10 & 124 & 39 & 121 \\
Mar 26, 2012 & 12 & 103 & 27 & 70 \\
\hline
\end{tabular}

stage occurred during all sampling period, except late winter (September) and spring (as established by the absence of undifferentiated animals) with densities between $11.4 \mathrm{ind} /$ $\mathrm{m}^{2}$ (August 2011) and $71.4 \mathrm{ind} / \mathrm{m}^{2}$ (April 2012) (Fig. 7).

\section{DISCUSSION}

The population of $B$. glaber studied herein showed high density. QUADRos et al. (2009) considered it a $K$-strategist species and mentioned that the populations might struggle to colonize new environments and maintain population stability in areas with anthropogenic influence (compared to habitat generalist species), unlike what was observed in this urban population.

The presence of "artificial" shelters may have given B. glaber conditions for survival in the area by providing favorable microhabitats and generating low temperature and humidity variation for the population, without affecting their resilience capacity (BorDALO et al., 2011). The food availability also might not have decreased with human activity in the area because large amounts of litter and fallen logs were observed in the study area over the 12 months of sampling. JABIN et al. (2004) found that isopod density was higher near woody debris. HeInZELManN et al. (1995) noted that in addition to other abiotic factors, soil texture had an influence on the Armadillidium vulgare (Latreille, 1804) spatial distribution. In the present study, the large standard deviations found for monthly densities were due to samples in which no individuals were found collected at points where the soil was drier, with high temperatures and low relative moisture. HoRNUNG (1991) observed that for Trachelipus nodulosus (Koch, 1838) and A. vulgare abundance was correlated with soil parameters and vegetation composition, respectively.

Even though no significant relationship was observed between density and abiotic variables in this study or in QUADROS \& ARAUJO (2007), other studies have indicated that terrestrial isopod abundance and life history aspects are closely linked to soil and litter temperature and moisture (Helden \& HaSSAll, 1998; Zimmer, 2004; Araujo \& Bond-Buckup, 2005; Sokolowicz \& Araujo, 
2013). Sunderland et al. (1976) reported that at low temperatures terrestrial isopods looked for warmer shelter by searching for deeper sites in the substrate. This vertical migration, both in the soil and litter, is the result of the soil fauna's sensory ability to shelter in the most appropriate locations during situations of population risk (VILLANI $e t$ al., 1999). This seems to be the pattern found in B. glaber, since abundance was observed to increase when a large decrease in soil and litter temperature occurred (low peaks, after an increase period), as demonstrated in July 2011 and April 2012 (winter and autumn, respectively). Balloniscus glaber's burrowing ability can protect it from desiccation and predation during cold and dry periods, but at the same time restricts it to soft and moist soil areas (QUADRos \& ARAujo, 2007), which in the present study may have contributed to the patchy distribution.

Trampling can alter the species richness, diversity, and abundance of arthropods. In a park in South Africa that large mammals crossing in the woods were found to be the determining factors in the surface soil arthropod assembly (Rivers-Moore \& SAMways, 1996). A similar event was observed by LEHVÄVIRTA et al. (2006), when an increase of passages in the fields by farm workers negatively influenced invertebrate frequency. Likewise, in a carabid beetles study in Finland, species richness and diversity were also negatively affected by trampling, with only one species increasing in abundance, resulting in a higher total catch in more impacted areas (GRANDCHAMP et al., 2000). In a small forest edge fragment formed by cutting, FARKAS \& VILISICS (2006) found the isopod Trachelipus ratzeburgii (Brandt, 1833), which is considered unusual in impacted environments. Prior to anthropogenic activities, the area was part of a single large forest, and the authors concluded that the population has survived the degradation event. This could be the expected scenario for B. glaber, since the area analyzed had gone through a similar event: a few other smaller fragments nearby were remnants of a previous large forest that had suffered deforestation and clearing of trails, walkways, and roads over the last two decades. In fact, $B$. glaber shows a similar pattern as the isopod Philoscia muscorum (Scopoli, 1763) in a disturbance gradient in Denmark, where the species was found in urban, suburban, and rural areas (VILISICs et al., 2007). Furthermore, in an impacted environment in Budapest, Hungary, native species, introduced species, restricted distribution species, widely distributed species, generalists, and specialists of terrestrial isopods were found (VILISICS \& HoRnung, 2009). Notably, the presence of Porcellio scaber Latreille, 1804 in a native forest was found to be related to the houses near the forest, which provided the typical scenario for synanthropic species (FERENTI \& CovaCIUMARCOV, 2012).

One of the most important life history traits of terrestrial isopods is fecundity and for iteroparous species, the total contribution of newborns during the breeding season. In this study, reproductive female $\mathrm{CW}$ amplitude and the intra-marsupial content were high, showing that individuals tend to reach sexual maturity at a younger age in this impacted urban environment. This earlier reproduction coupled with a longer reproductive period, spring and summer continuing until mid-autumn (May), differs from those results obtained by QuADros \& ARAUJo (2007) in which reproduction ceased by the end of summer. Such an earlier and extended breeding period could be related to temperature and photoperiod, the most important abiotic factors that regulate reproduction in isopods (MocQUARD et al., 1989). In the impacted area, the plant cover is sparser, and as a consequence, sunlight reaches the soil earlier and for longer periods, daily and seasonally, inducing the earlier onset of reproduction (MOCQUARD et al., 1989). In the present population, both temperature and photoperiod may have provided warmer and longer days, allowing for vitellogenesis and parturial molt (SteEL, 1980; MADHAVAN $\&$ ShribBS, 1981).

The highest ARF rate occurring in late summer, unlike in the nonurban area, where it took place in spring. Given the important role that females play in maintaining population stability and that their size is strongly related to fecundity (ARAUJo \& BOND-BUCKUP, 2005; QUADROs et al., 2009; SoKolowicz \& AraUjo, 2013), this study suggests that the reproductive event is not negatively affected by human impact. In terms of percentage of ovigerous females, an overall comparison with the previous study (QUADROS \& ARAUJO, 2007) demonstrates an IRM similarity in both populations, with peaks in different months. The same applies to the frequency of mancae, with most of them collected in the summer, unlike the work of QUADROs \& Araujo (2007), in which $46 \%$ of mancae were sampled in the spring. The large mancae peak in February was expected as a result of a higher ARF density in January given the ovigerous females' incubation period (QuADros et al., 2009), as well as mancae absence after the reproductive period because the animals would be unable to survive the winter months (ARAujo \& Bond-BuCKuP, 2005). Due to the "undifferentiated" category, a lack of "younger" individuals was observed (i.e., the early stage of youth, when the animal is no longer at the manca stage) in the population for approximately four months (SeptemberDecember 2011), probably due to the absence of mancae in previous months.

PaOletti \& Cantarino (2002), working with Trachelipus rathkii (Brandt, 1833), found a greater female prevalence in an impacted rural area than in preserved environments. This also occurred with terrestrial amphipods in newly colonized environments (WILDISH, 1971). However, the sex ratio of terrestrial isopod populations may vary between populations and species (DANGERFIELD \& HASSALL, 1994). Even so, a juvenile female predominance was observed in 1- and 2-month-old isopods [according to the growth curve (MeINHARDT et al., 2007) and life table (Quadros \& Araujo, 2007)] in the population at the beginning of the winter (July 2011) and during the late summer (April 2012) in the impacted area. This pattern reflects the individuals' growth time to reach adulthood and 
sexual maturity for the reproduction period. Knowing that the reproductive ability first occurs at approximately 7.5 months of age for this species (QUADRos et al., 2009), and that the spring and summer egg production in this study were similar (productive beginning, followed by a decline), the females that derived from the first juvenile peak have a great chance of reproducing in the late spring and having their offspring born in the early summer. The April females would mature in late winter when environmental conditions are more favorable for reproduction, and their mancae would be released from their pouch in the beginning of the following spring. A second reproductive event could potentially occur in this latter case, although with a minimal chance, corroborating the B. glaber iteroparous pattern (Quadros \& Araujo, 2007; Quadros et al., 2009). As reported by QUADROS \& ARAUJO (2007) for the natural environment, the population in this study also showed a low proportion of ovigerous females and low juvenile mortality, although individuals reached sexual maturity earlier in the impacted urban area.

The intra-marsupial population mortality rate of $B$. glaber in this study was $6.7 \%$, which is high compared with those values observed for A. floridana of less than $1 \%$ (Araujo \& Bond-Buckup, 2005) and $0.8 \%$ for $P$. muscorum, between $0.9 \%$ and $2.7 \%$ for Burmoniscus ocellatus (Verhoeff, 1928), between $1.4 \%$ and $3.0 \%$ for Formosillo raffaelei (Arcangeli, 1927), and between 0.5\% and $1 \%$ for Orodillo maculatus Arcangeli, 1952 (MA et al., 1991). Rates above 6\%, as found for A. vulgare are high (PARis \& Pitelka, 1962; Al-DabbaG \& Block, 1981), even though they vary greatly between species, between different populations of the same species (ARAUJO \& BOND-BUCKUP, 2005), and between different environmental conditions (HoRNUNG \& WARBURG, 1994). The population density of B. glaber is high irrespective the high marsupial mortality.

According to the present study, the population parameters presented in the monthly data obtained through an uninterrupted year of sampling suggest that $B$. glaber can tolerate habitat disturbance by surviving fragmentation and anthropogenic events despite being considered a $K$-strategist habitat specialist species.

Acknowledgments. The authors thank CAPES (Coordenação de Aperfeiçoamento de Pessoal de Nível Superior) for the scholarship granted to DCK, CNPq (Conselho Nacional de Pesquisa e Desenvolvimento) for the productivity fellowship granted to PBA. Also, we thank the colleagues from the Carcinology Lab of the Graduate Program in Animal Biology, Instituto of Biociências, Universidade Federal do Rio Grande do Sul.

\section{REFERENCES}

Al-DabbaG, K. Y. \& Block, W. 1981. Population ecology of a terrestrial isopod in two breckland grass heaths. Journal of Animal Ecology 50:61-77.

Almerão, M. P.; Mendonça JR., M. de; Quadros, A. F.; Pedó, E.; Silva, L. G. R. \& Araujo, P. B. 2006. Terrestrial isopod diversity in the subtropical Neotropics: Itapuã State Park, southern Brazil. Iheringia, Série Zoologia 96(4):473-477.

Araujo, P. B. \& Bond-Buckup, G. 2005. Population structure and reproductive biology of Atlantoscia floridana (van Name, 1940) (Crustacea, Isopoda, Oniscidea) in southern Brazil. Acta Oecologica 28:289-298.
Araujo, P. B.; Quadros, A. F.; Augusto, M. M. \& Bond-Buckup, G. 2004. Postmarsupial development of Atlantoscia floridana (van Name, 1940) (Crustacea, Isopoda, Oniscidea): sexual differentiation and size at onset of sexual maturity. Invertebrate Reproduction \& Development 45:221-230.

Bond-Buckup, G.; Buckup, L. \& Araujo, P. B. 2003. Crustáceos. In: Fontana, C. S.; Bencke, G. A. \& Reis, R. E. eds. Livro Vermelho da Fauna Ameaçada de Extinção no Rio Grande do Sul. Porto Alegre, EDIPUCRS. 632p.

Bordalo, M. D.; Ferreira, S. M.; Cardoso, P. G.; Leston, S. \& PARDAL, M. A. 2011. Resilience of an isopod population (Cyathura carinata) to multiple stress factors in a temperate estuarine system. Hydrobiologia 671:13-25.

Dangerfield, J. M. \& Hassall, M. 1994. Shelter site use and secondary sex ratios in the woodlice Armadillidium vulgare and Porcellio scaber (Crustacea: Isopoda). Journal of Zoology 233(1):1-7.

EmLen, S. T. \& OrInG, L. W. 1997. Ecology, sexual selection, and the evolution of mating systems. Science 197(4300):215-223.

FARKAS, S. \& Vilisics, F. 2006. A Mecsek szárazföldi ászkarák együttesei (Isopoda: Oniscidea). Folia Comloensis 15:25-34

Ferenti, S. \& Covaciu-Marcov, S-D. 2012. Comparison of terrestrial isopod (Isopoda, Oniscidea) assemblages from two types of forests from North Western Romania. Ecologia Balkanica 4(2):61-67.

Grandchamp, A. C.; Niemelä, J. \& Kotze, J. 2000. The effects of trampling on assemblages of ground beetles (Coleoptera, Carabidae) in urban forests in Helsinki, Finland. Urban Ecosystem 4:321-332.

Hassall, M.; Zimmer, M. \& Loureiro, S. 2005. Questions and possible new directions for research into the biology of terrestrial isopods. European Journal of Soil Biology 41:57-61.

Heinzelmann, F.; Crawford, C. S.; Molles JR, M. C. \& Warburg, M. R. 1995. Microhabitat selection by Armadillidium vulgare in a riparian forest: lack of apparent influence by leaf litter food quality. Crustacean Issues 9:133-143.

Helden, A. J. \& Hassall, M. 1998. Phenotypic plasticity in growth and development rates of Armadillidium vulgare (Isopoda: Oniscidea). Israel Journal of Zoology 44:379-394.

HoRNUNG, E. 1991. Isopod distribution in a heterogeneous grassland habitat. In: Juchault, P. \& Mocquard, J. P. eds. Third Symposium on the Biology of Terrestrial Isopods. France, Université de Poitiers. p. 73-79.

Hornung, E. \& Warburg M. R. 1994. Oosorption and oocyte loss in a terrestrial isopod under stressful conditions. Tissue \& Cell 26(2):277-284.

Hornung, E.; TóthméRÉsz, B.; Magura, T. \& Vilisics, F. 2007. Changes of isopod assemblages along an urban-suburban-rural gradient in Hungary. European Journal of Soil Biology 43:158-165.

INMET. 2012. Brazilian National Institute of Meteorology. Available at $<$ http://www.inmet.gov.br $>$ (in Portuguese). Accessed on 2011 and 2012 .

JABIN, M.; MOHR, D.; KAPPES, H. \& TOPP, W. 2004. Influence of deadwood on density of soil macro-arthropods in a managed oak-beech forest. Forest Ecology and Management 194:61-69.

JONES, E. L. \& LEATHER, S. R. 2012. Invertebrates in urban areas: A review. European Journal of Entomology 109(4):463-478.

KITAHARA, M. \& FUJII, K. 1994. Biodiversity and community structure of temperate butterfly species within a gradient of human disturbance: an analysis based on the concept of generalist vs specialist strategies. Researches on Population Ecology 36:187-199.

Kitahara, M.; Sei, K. \& FujiI, K. 2000. Patterns in the structure of grassland butterfly communities along a gradient of human disturbance: further analysis based on the generalist/specialist concept. Population Ecology 42:135-144.

Lehvävirta, S.; Kotze, D. J.; Niemelä, J.; MäntysaAri, M. \& O’hara, R. B. 2006. Effects of fragmentation and trampling on carabid beetle assemblages in urban woodlands in Helsinki, Finland. Urban Ecosystem 9:13-26.

Lopes, E. R. C.; Mendonça Jr, M. S.; Bond-Buckup, G. \& Araujo, P. B. 2005. Oniscidea diversity across three environments in an altitudinal gradient in northeastern Rio Grande do Sul, Brazil. European Journal of Soil Biology 41:99-107. 
Ma, H. H. T.; Dudgeon, D. \& Lam, P. K. S. 1991. Seasonal changes in populations of three sympatric isopods in a Hong Kong Forest. Journal of Zoology 224:365-374.

MadhaVAn, K. \& ShribBS, J. M. 1981. Role of photoperiod and low temperature in the control of ovigerous molt in the terrestrial isopod, Armadillidium vulgare (Latreille, 1804). Crustaceana 41(3):263-270.

Magrini, M. J.; Freitas, A. V. L. \& Uehara-Prado, M. 2011. The effects of four types of anthropogenic disturbances on composition and abundance of terrestrial isopods (Isopoda: Oniscidea). Zoology 28(1):63-71.

MaguRA, T.; HoRnung, E. \& TóTHMÉRÉSz, B. 2008. Abundance patterns of terrestrial isopods along an urbanization gradient. Community Ecology 9(1):115-120.

Magura, T.; Tóthmérész, B. \& MolnáR, T. 2004. Changes in carabid beetle assemblages along an urbanization gradient in the city of Debrecen, Hungary. Landscape Ecology 19:747-759.

Meinhardt, H.; Quadros, A. F. \& Araujo, P. B. 2007. Growth curve of Balloniscus glaber Araujo and Zardo (Crustacea, Isopoda, Oniscidea) from Parque Estadual de Itapuã, Rio Grande do Sul, Brazil. Revista Brasileira de Zoologia 24:1108-1112.

Mocquard, J. P.; Juchault, P. \& Souty-Grosset, C. 1989. The role of environmental factor (temperature and photoperiod) in the reproduction of the terrestrial isopod Armadillidium vulgare (Latreille, 1804). Monitore Zoologico Italiano - Italian Journal of Zoology (Monografia) 4:455-475.

Morellato, L. P. C. \& HadDAD, C. F. B. 2000. Introduction: the Brazilian Atlantic forest. Biotropica 32:786-792.

Paoletti, M. G. \& Cantarino, C. M. 2002. Sex ratio alterations in terrestrial woodlice populations (Isopoda: Oniscidea) from agroecosystems subjected to different agricultural practices in Italy. Applied Soil Ecology 19:113-120.

Paris, O. H. \& PitelKa, F. A. 1962. Population characteristics of the terrestrial isopod Armadillidium vulgare in California grassland. Ecology 43:229-248.

Peel, M. C.; Finlayson, B. L. \& Mcmahon, T. A. 2007. Updated world map of the Köppen-Geiger climate classification. Hydrology and Earth System Sciences 11:1633-1644.

QuAdRos, A. F. \& ARAuJo, P. B. 2007. Ecological traits of two neotropical oniscideans (Crustacea: Isopoda). Acta Zoologica Sinica 53:241-249.
Quadros, A. F.; Caubet, Y. \& Araujo, P. B. 2009. Life history comparison of two terrestrial isopods in relation to habitat specialization. Acta Oecologica 35:243-249.

Rio Grande do Sul. 2014. Decreto n. 51.797, de 8 de setembro de 2014. Declara sobre as espécies da Fauna Silvestre ameaçadas de extinção no Estado do Rio Grande do Sul. Porto Alegre, Diário Oficial, p. 2.

Rivers-Moore, N. A. \& SAMWAYS, M. J. 1996. Game and cattle trampling, and impacts of human dwellings on arthropods at a game park boundary. Biodiversity and Conservation 5:1545-1556.

Sokolowicz, C. C. \& Araujo, P. B. 2013. Reproductive pattern of the neotropical terrestrial isopod Benthana cairensis (Isopoda: Philosciidae). Journal of Crustacean Biology 33(2):210-217.

Steel, C. G. H. 1980. Mechanisms of coordination between moulting and reproduction in terrestrial crustacean. Biological Bulletin 159:206-218.

Sunderland, K. D.; Hassall, M. \& Sutton, S. L. 1976. The population dynamics of Philoscia muscorum (Crustacea Oniscoidea) in a dune grassland ecosystem. Journal of Animal Ecology 45:487-506.

SutTON, S. L. 1968. The population dynamics of Trichoniscus pusillus and Philoscia muscorum (Crustacea: Oniscoidea) in limestone grassland. Journal of Animal Ecology 37:425-444.

Sutton, S. L.; Hassall, M.; Willows, R.; Davis, R. C.; Grundy, A. \& Sunderland, K. D. 1984. Life histories of terrestrial isopods. Symposium of Zoological Society of London 53:269-294.

VILISICS, F. \& HoRNUNG, E. 2009. Urban areas as hot-spots for introduced and shelters for native isopod species. Urban Ecosystem 12:333-345.

Vilisics, F.; EleKa, Z.; LöVeI, G. L. \& Hornung, E. 2007. Composition of terrestrial isopod assemblages along an urbanisation gradient in Denmark. Pedobiologia 51:45-53.

Vilisics, F.; Sólymos, P.; Nagy, A.; Farkas, R.; Kemencei, Z. \& Hornung, E. 2011. Small scale gradient effects on isopods (Crustacea: Oniscidea) in karstik sinkholes. Biologia, Section Zoology 66(3):499-505.

Villani, M. G.; Alle, L. L.; Diaz, A. \& Robbins, P. S. 1999. Adaptative strategies of edaphic arthropods. Annual Review of Entomology 44:233-256.

WILDISH, D. J. 1971. Adaptive significance of a biased sex ratio in Orchestia. Nature 233:54-55.

ZIMMER, M. 2004. Effects of temperature and precipitation on flood plain isopod community: a field study. European Journal of Soil Biology 40(3-4):139-146. 